Article

\title{
Investigation of Anaerobic Digestion of the Aqueous Phase from Hydrothermal Carbonization of Mixed Municipal Solid Waste
}

\author{
Kameron J. Adams (D), Ben Stuart and Sandeep Kumar* \\ Department of Civil \& Environmental Engineering, Old Dominion University, Norfolk, VA 23529, USA; \\ kadam006@odu.edu (K.J.A.); bstuart@odu.edu (B.S.) \\ * Correspondence: skumar@odu.edu
}

Citation: Adams, K.J.; Stuart, B.; Kumar, S. Investigation of Anaerobic Digestion of the Aqueous Phase from Hydrothermal Carbonization of Mixed Municipal Solid Waste. Biomass 2021, 1,61-73. https://doi.org/10.3390/ biomass 1010005

Academic Editors: Paolo Defilippis and Lasse Rosendahl

Received: 30 April 2021

Accepted: 26 August 2021

Published: 6 September 2021

Publisher's Note: MDPI stays neutral with regard to jurisdictional claims in published maps and institutional affiliations.

Copyright: (c) 2021 by the authors. Licensee MDPI, Basel, Switzerland. This article is an open access article distributed under the terms and conditions of the Creative Commons Attribution (CC BY) license (https:/ / creativecommons.org/licenses/by/ $4.0 /)$.

\begin{abstract}
In 2017, the United States Environmental Protection Agency (EPA) reported that Americans generated over 268 million tons of municipal solid waste (MSW). The majority (52\%) of this waste ends up in landfills, which are the third largest source of anthropogenic methane emissions. Improvements in terms of waste management and energy production could be solved by integrating MSW processing with hydrothermal carbonization (HTC) and anaerobic digestion (AD) for converting organic carbon of MSW to fuels. The objectives of this study were to (a) investigate HTC experiments at varying temperatures and residence times (b) evaluate aqueous phase and solids properties, and (c) perform $\mathrm{AD}$ bench scale bottle test on the aqueous phase. A mixture of different feedstock representing MSW was used. HTC at $280^{\circ} \mathrm{C}$ and $10 \mathrm{~min}$ yielded the highest total organic carbon (TOC) of $8.16 \mathrm{~g} / \mathrm{L}$ with biogas yields of $222 \mathrm{~mL}$ biogas/g TOC. Results showed that AD of the aqueous phase from a mixed MSW feedstock is feasible. The integrated approach shows organic carbon recovery of $58 \%$ (hydrochar and biogas). This study is the first of its kind to investigate varying temperature and times for a heterogeneous feedstock (mixed MSW), and specifically evaluating HTC MSW aqueous phase anaerobic biodegradability.
\end{abstract}

Keywords: hydrothermal carbonization; anaerobic digestion; municipal solid waste; waste to energy; mixed feedstocks; biogas

\section{Introduction}

In 2017, the United States Environmental Protection Agency (EPA) reported that Americans generated over 268 million tons of municipal solid waste (MSW); 52\% (landfilled), 13\% (incinerated), and 35\% (recycled/composted) [1]. MSW landfills are the third largest source of anthropogenic methane emissions which have 23 times more greenhouse gas trapping potential than $\mathrm{CO}_{2}$. Improvements in terms of waste management and energy production could be solved by integrating MSW processing with hydrothermal carbonization (HTC) and anaerobic digestion (AD) to reduce waste to landfills and maximize the organic carbon and resource recovery.

HTC is defined as a combined dehydration and decarboxylation of an organic feedstock under subcritical water/hydrothermal medium to enrich its carbon content making it comparable to bituminous grade coal's heating values (24-27 MJ/kg). Literature reports operating conditions of HTC ranging from $180^{\circ} \mathrm{C}$ to $320^{\circ} \mathrm{C}$ based on different feedstock which produces three main products and average product yields; hydrochar "green coal" $(45-70 \%)$, aqueous phase (5-25\%) and gases which are mainly $\mathrm{CO}_{2}(2-5 \%)$ [2]. HTC is observed as a scalable technique to convert wet biomass (e.g., MSW) to carbon-rich solid fuels. HTC offers many advantages as one of the most efficient processes for carbon fixation in solid fuels for a wet feedstock in a short residence time; however, heat recovery and aqueous phase (with 20-45\% total organic carbon (TOC)) recycling are essential to its waste to energy feasibility. Previous studies [2-6] have shown that the HTC aqueous phase can be amendable for subsequent biological treatment, such as AD. A recent study that used HTC 
of corn silage followed by $\mathrm{AD}$ of the aqueous phase (without any pretreatment) achieved $16.3 \mathrm{~L} \mathrm{CH}_{4} / \mathrm{Kg}$ of wet fresh matter, further proving that the aqueous phase has much potential for higher biogas yields [4]. Another group [3] performed batch HTC experiments using agricultural residue as feedstock; and calculated biogas potential for the resulting process water (aqueous phase) after HTC. For the aqueous phase, they reported, TOC $(12-26 \mathrm{~g} / \mathrm{L})$ and $\mathrm{pH}(3-5)$, supporting the idea that the aqueous phase has great potential for further treatment with AD. However, the research studies on anaerobic biodegradability of HTC MSW aqueous phase has not been done [2]. There are several chemical compounds present in the HTC aqueous phase such as organic acids (e.g., lactic acid and acetic acid), aromatics, and phenolic compounds [7]. Some of these compounds could potentially be recovered as byproducts or further processed after pretreatments to increase biogas yields. Nationwide AD systems are projected to reduce cumulative energy consumption by nearly 15 million T/J and reduce GHG emissions by 7.2 billion tons of $\mathrm{CO}_{2}$ over 50 years and have been used to treat MSW; however, they are not large scale in the U.S. because of economic feasibility and disadvantages including weeks to months of solids retention time for biogas energy production [8].

There have been fewer studies conducted on complex waste streams for sustainable waste management, but HTC offers an innovative way to treat MSW feedstocks that contain high moisture and high carbon content. Berge et al. investigated HTC of MSW because little work has been done exploring the carbonization of theses complex waste streams in order to evaluate HTC as a sustainable waste management technique. The purpose of their study was to determine the feasibility of hydrothermally carbonizing model municipal waste streams especially those that would typically go to the landfill. Their objectives included evaluating the environmental implications associated with the carbonization of representative municipal waste streams, evaluating properties of hydrochar, and determining carbonization energetics associated with each waste stream. One major finding was that $20-37 \%$ of initial carbon was transferred to the aqueous phase after HTC of mixed MSW feedstock, which can be recovered for energy; however, in their study, carbonization experiments were not optimized, and the aqueous phase was not tested for digestibility [2].

Advantages of using HTC over conventional waste management methods include no required separation of feedstock, wet feedstocks can be used without drying, and using lower temperatures and less energy compared to other thermal treatments such as incineration and pyrolysis. AD residence time of the aqueous phase has been shown to be faster than conventional solids (MSW organics) digestion [9]. The importance of this research is timely in terms of solid waste management and waste to energy. Commercial scale HTC is an emerging industry with three large scale operational plants in the world; handling of the aqueous phase is an important factor in terms of upscaling HTC for sustainable waste management practices [10]. If this proposed integrated (HTC + AD) process using MSW is proven to be feasible techno-economically, this could be monumental in terms of mitigating many environmental issues associated with conventional incineration and landfilling such as air pollution, groundwater water pollution and limited landfill space.

To specifically understand product composition after HTC of mixed MSW, and HTC MSW aqueous phase biodegradability while building on some of the work done by Berge et al., the purpose of this particular study was to (a) investigate carbonization experiments at different temperatures $\left(250,280,310^{\circ} \mathrm{C}\right)$ and residence times $(10 \mathrm{~min}, 1 \mathrm{~h}, 6 \mathrm{~h})(\mathrm{b})$ evaluate aqueous phase and hydrochar properties (c) perform $\mathrm{AD}$ bench scale bottle test on the aqueous phase to generate experimental data on biogas yields to understand biodegradability (Figure 1). There are many studies on hydrothermal treatment of a homogeneous biomass feedstock (e.g., grasses, woods, foods) and a few studies combining HTC and AD [3,4,9,11-13]. This study is the first of its kind to investigate varying temperature and times for a heterogeneous feedstock such as model mixed MSW that would typically go to the landfill, and further evaluating HTC MSW aqueous phase anaerobic biodegradability. 


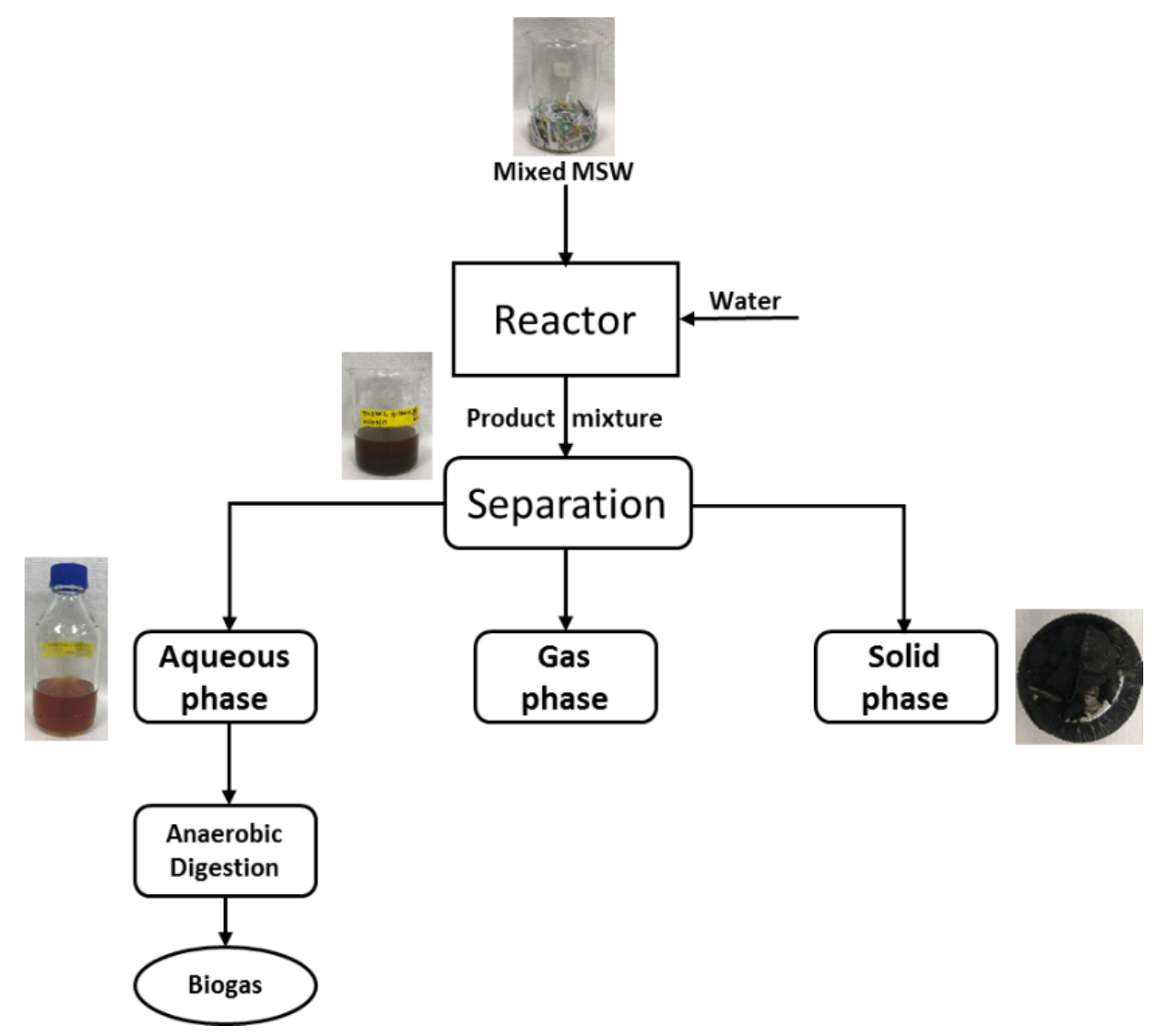

Figure 1. Schematic diagram of the overall process flow.

\section{Materials and Methods}

\subsection{Feedstock}

A mixture of known composition (paper, plastic, metal, glass, food) representing waste that typically goes to the landfill was created for the HTC feedstock (wt. \% basis). Mixed MSW was simulated using the following materials, and deionized water (DI) was added to the mixture to obtain a solids concentration of $20 \mathrm{wt} . \% ; 45.5 \%$ paper (shredded discarded office paper), 9.6\% glass (crushed glass bottles), 16.4\% plastic (shredded plastic bottles), $17.6 \%$ food (rabbit food pellets), 10.9\% metal (shredded aluminum cans) [2].

\subsection{Hydrothermal Carbonization Experiments}

HTC of the mixed MSW feedstock was conducted using a $500 \mathrm{~mL}$ high pressure batch reactor (PARR 4570 Series). Literature reports HTC conditions ranging from $180-320{ }^{\circ} \mathrm{C}$ and residence times ranging from $5 \mathrm{~min}-12 \mathrm{~h} \mathrm{[14]}$. The following process conditions (250, $\left.280,310^{\circ} \mathrm{C}\right)$ and $\left(10 \mathrm{~min}, 1 \mathrm{~h}\right.$ and $6 \mathrm{~h}$ ) were chosen based on lower $\left(250^{\circ} \mathrm{C}\right)$ and high range $\left(310^{\circ} \mathrm{C}\right) \mathrm{HTC}$ temperatures with a short, mid and long duration residence time, to compare HTC MSW end products and carbon distribution.

After the mixed MSW simulation feedstock was made and DI water was added for $20 \mathrm{wt} . \%$ solids, the experiment was run at $250,280,310{ }^{\circ} \mathrm{C}$ for $10 \mathrm{~min}, 1 \mathrm{~h}$ and $6 \mathrm{~h}$ in triplicate. It should be noted that $310{ }^{\circ} \mathrm{C}$ was only run for $10 \mathrm{~min}$ and $1 \mathrm{~h}$. The process included a heating phase, reaction phase (when subcritical conditions and desired temperature were met), and cooling phase. After maintaining the desired temperature and time under autogenous pressure conditions, the reactor was rapidly cooled to ambient conditions using water through a cooling coil. After the reaction had taken place, the resulting mixture was placed in a beaker and the $\mathrm{pH}$ of aqueous phase was measured. The product mixture was vacuum filtered $(1.5 \mu \mathrm{m}$, Whatman $47 \mathrm{~mm}$ glass microfiber filters). Subsequently, solids 
were placed in the oven at $105^{\circ} \mathrm{C}$ for $24 \mathrm{~h}$ to remove moisture and the aqueous phase was measured and stored in the freezer $\left(4^{\circ} \mathrm{C}\right)$ for further analysis.

\subsection{Anaerobic Digestion \\ Methods and Test Apparatus}

$\mathrm{AD}$ was carried out using a batch bottle test and biogas yields were measured using water displacement. Graduated cylinders were inverted in $45 \mathrm{~L}$ bins (Sterilite) filled with water and gas production was monitored daily in $\mathrm{mL}$ of biogas produced. The following five HTC MSW aqueous phases were used for analysis; $250^{\circ} \mathrm{C}(10 \mathrm{~min}, 1 \mathrm{~h}), 280^{\circ} \mathrm{C}(10 \mathrm{~min}$, $1 \mathrm{~h}), 310{ }^{\circ} \mathrm{C}(1 \mathrm{~h})$; each condition was done in triplicate. For $\mathrm{AD}$, an average of $1 \mathrm{~g}$ of chemical oxygen demand (COD) $(\sim 0.3 \mathrm{~g}$ TOC) was added to the bottles and $400 \mathrm{~mL}$ of inoculum. The inoculum (TS $=4.5 \%, \mathrm{VS}=77 \%$ ) was obtained from anaerobic digesters at Hampton Roads Sanitation District (HRSD) Atlantic wastewater treatment plant (Virginia Beach, VA, USA). DI water was added to the $450 \mathrm{~mL}$ line to ensure equal headspace. The bottles were purged with nitrogen for $1 \mathrm{~min}$ to ensure anaerobic conditions in the headspace and were immediately sealed with rubber caps designed with inlets for gas measurements. One-eighth inch plastic tubes (Aqua Culture Standard Airline Tubing) were placed on the inlets and the tubes were connected from the bottle into the inverted graduated cylinder in the tubs filled with water. For 15 days, digestion bottles were placed in a heated water bath shaker (New Brunswick Scientific G-76D) at $37^{\circ} \mathrm{C}$ (to maintain mesophilic conditions) and $40 \mathrm{rpm}$ for mixing. Biogas was monitored daily and recorded in $\mathrm{mL}$ of biogas produced. Gas volume was corrected for water vapor, normal conditions $\left(0{ }^{\circ} \mathrm{C}\right.$ and $\left.1 \mathrm{~atm}\right)$ and measured by subtracting the gas yield from the inoculum as a control. Gas chromatography (SRI 8610C) equipped with TCD/FID detectors was used to monitor presence of methane and carbon dioxide.

\subsection{Analytical Methods}

\subsubsection{Hydrothermal Carbonization and Products: Solids and Gases}

All solids (HTC MSW starting material and hydrochar) were tested for total solids, volatile solids and ash as described in ASTM E1756-08, EPA Method 1684, ASTM E1755-01, respectively. Elemental analysis (Thermo Finnigan Flash EA 1112 elemental analyzer) with 2,5-Bis (5-tert-butylbenzoxazol-2-yl) thiophene (BBOT) standard (certified no. 20214710/03/2015, ThermoFisher Scientific, Cambridge, UK) was done in triplicate for starting material and HTC MSW hydrochar. Solids wt.\% yield and higher heating value (HHV) using a modified Dulong equation [15], was calculated for the HTC MSW hydrochar. Thermogravimetric analysis (TGA) of hydrochar was performed using TGA-50H (Shimadzu Corporation) following ASTM D7582-15 standards to evaluate the fuel properties of the hydrochar. Burning profiles from the TGA are used to evaluate classes of coal (e.g., lignite, bituminous); thus, the burning profile was evaluated using $10 \mathrm{mg}$ of the $280^{\circ} \mathrm{C}$ at $10 \mathrm{~min}$ hydrochar. Compressed air was used at $50 \mathrm{~mL} / \mathrm{min}$ with temperature ramped from $25^{\circ} \mathrm{C}$ to $750{ }^{\circ} \mathrm{C}$ at $12.5^{\circ} \mathrm{C} / \mathrm{min}$ for $60 \mathrm{~min}$ and was held at $750{ }^{\circ} \mathrm{C}$ for $30 \mathrm{~min}$. Brunauer, Emmett, and Teller (BET) analysis was carried out using a NOVA 2200e surface area and pore size analyzer (Quantachrome Instruments) to determine surface area of HTC MSW hydrochar; $0.2 \mathrm{~g}$ of sample was degassed for $4 \mathrm{~h}$ at $95^{\circ} \mathrm{C}$. Following a backfill with helium, the mass of the degassed sample was recorded. The sample cell containing the sample was then bathed in liquid nitrogen at $-196{ }^{\circ} \mathrm{C}$ during the analysis period. The multi-point BET surface area of the sample was then measured. HTC MSW gas phase yields were calculated using the difference of the solid and aqueous phase yields.

\subsubsection{Aqueous Phase}

HTC MSW aqueous phase was analyzed for total solids, volatile solids and ash as described in ASTM E1756-08, EPA Method 1684, ASTM E1755-01, respectively. They were also tested for TOC and TN (total organic carbon/total nitrogen (TOC/TN) analyzer TOC-VCSN, Shimadzu equipped with an ASI-V auto sampler), COD using (HACH COD 
20-1500 mg/L) digestion tubes and HACH DR/890 Colorimeter, and pH (Fisherbrand pH paper). Sugars and organic acids were measured by Thermo Scientific Dionex Ultimate 3000 HPLC equipped with Aminex HPX-87P column (sugars), and Aminex HPX-87H column (organic acids), and RefractoMax521 RI (refractive index) detector. All analyses were done in triplicate.

\section{Results and Discussion}

\subsection{Hydrothermal Carbonization and Carbon Distribution}

HTC was carried out at three different temperatures $\left(250,280,310^{\circ} \mathrm{C}\right)$ and three residence times (10 $\mathrm{min}, 1 \mathrm{~h}, 6 \mathrm{~h})$ in order to investigate the effects of varying temperature and times for the mixed MSW feedstock. These temperatures were chosen as low, medium, and high range temperatures. Although residence times vary, times were chosen to represent a shorter to longer residence time. Any time over $6 \mathrm{~h}$ was ruled out because increased energy usage; HTC at $310{ }^{\circ} \mathrm{C}$ for a residence time of $6 \mathrm{~h}$ was not performed because of this higher temperature range. One previous study (using a $160 \mathrm{~mL}$ reactor at $250{ }^{\circ} \mathrm{C}$ for $20 \mathrm{~h}$ ) was done for this mixed MSW feedstock; however, varying temperature and times were not investigated or optimized as it was not the focus of their research [2]. For this set of experiments, mass balance shows that $22-48 \%$ of carbon remained in the solid phase (hydrochar), $33-45 \%$ in the aqueous phase and $15-44 \%$ in the gas phase (Figure 2). The gas phase was calculated from the subtraction of aqueous and solid phases. Literature reports that the main composition of the HTC gas phase is carbon dioxide and trace amounts of $\mathrm{CO}, \mathrm{CH}_{4}$, and $\mathrm{H}_{2}$ gases [16]. It should be stated as in many studies on HTC, that it is difficult to make direct comparisons especially with hydrochar content as all HTC factors (temperature, time, pressure, reactor design, concentration) all influence carbonization. The condition of $280^{\circ} \mathrm{C}$ and $10 \mathrm{~min}$ yielded the highest carbon percentage in the aqueous phase $(45 \%)$. By raising the temperature $30^{\circ} \mathrm{C}$ from $250^{\circ} \mathrm{C}$, the residence time was decreased from $6 \mathrm{~h}$ to $10 \mathrm{~min}$ producing more carbon in the aqueous phase, less gas, and a solids percentage that of a longer residence time (Figure 2).

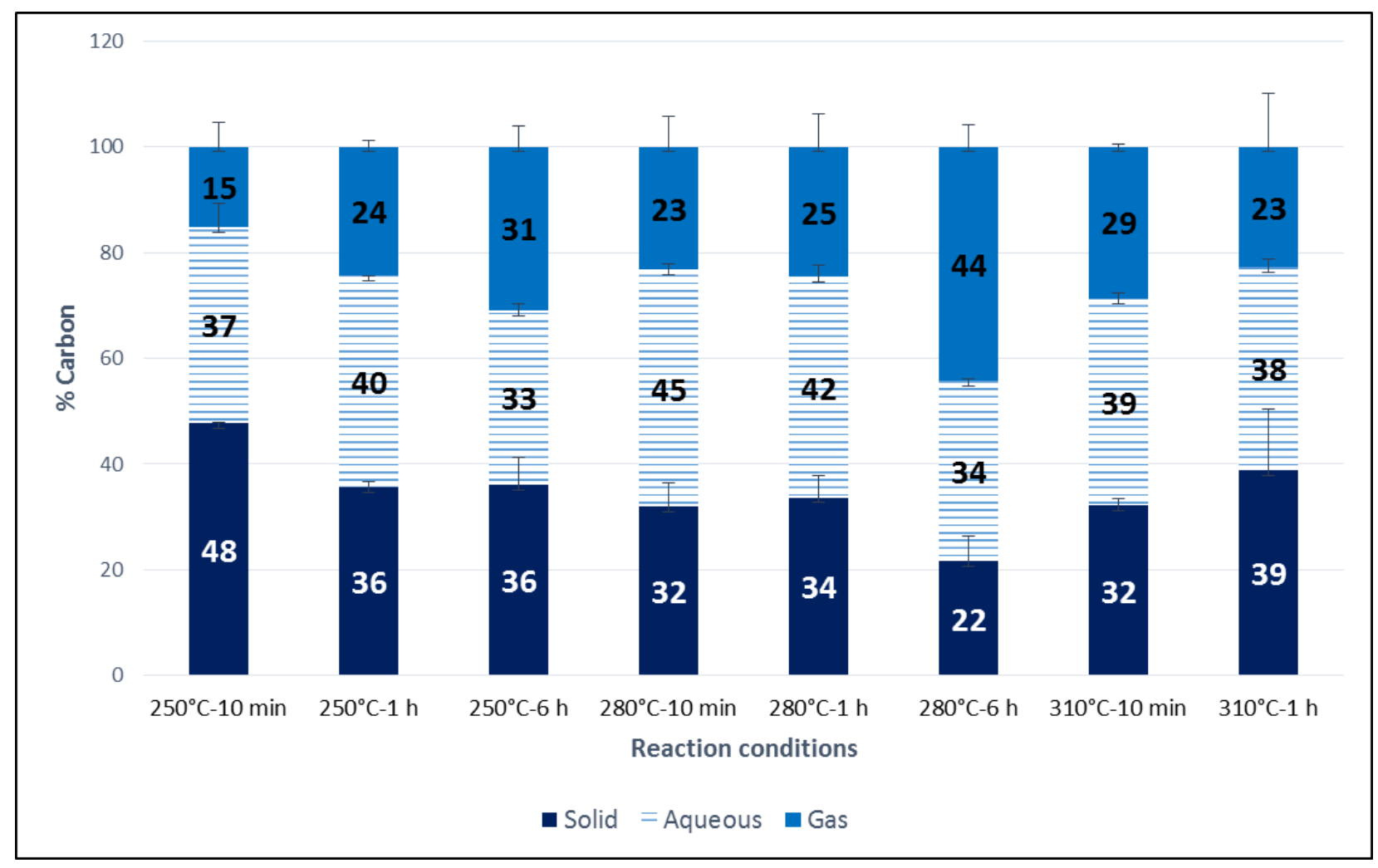

Figure 2. Distribution of carbon after HTC. Values are average of triplicate analysis. Error bars represent the standard deviation. 


\subsection{Aqueous Phase Composition}

HTC MSW aqueous phase carbon percent yields ranged from $34-45 \%$ aligning with previous literature $[3,4]$. The condition of $280{ }^{\circ} \mathrm{C}$ at $10 \mathrm{~min}$ yielded the highest TOC at $8.16 \mathrm{~g} / \mathrm{L}$ with others ranging from 6-7 g/L (Figure 3). Literature reports HTC aqueous phase ranging from 5-20 g/L [3]. A similar study done by Berge et al. using a similar feedstock reported aqueous phase TOC of $20 \mathrm{~g} / \mathrm{L}$ and COD of $60 \mathrm{~g} / \mathrm{L}$. This reaction took place in a much smaller reactor $(160 \mathrm{~mL})$ for a longer time $(20 \mathrm{~h})$ at $250{ }^{\circ} \mathrm{C}$, which could be a reason for higher aqueous phase TOC and COD yields compared to those done with a $500 \mathrm{~mL}$ reactor used for this study. TOC tended to decrease as temperature increased. An explanation for this is that the water soluble organics are intermediates in the formation of gas and oil/char; a higher percentage of gaseous compounds are a result of longer carbonization as can be seen with the reactions at $6 \mathrm{~h} \mathrm{[17].} \mathrm{COD} \mathrm{values} \mathrm{yielded} \mathrm{higher}$ amounts than TOC, which shows the presence of inorganics in the aqueous phase [9].

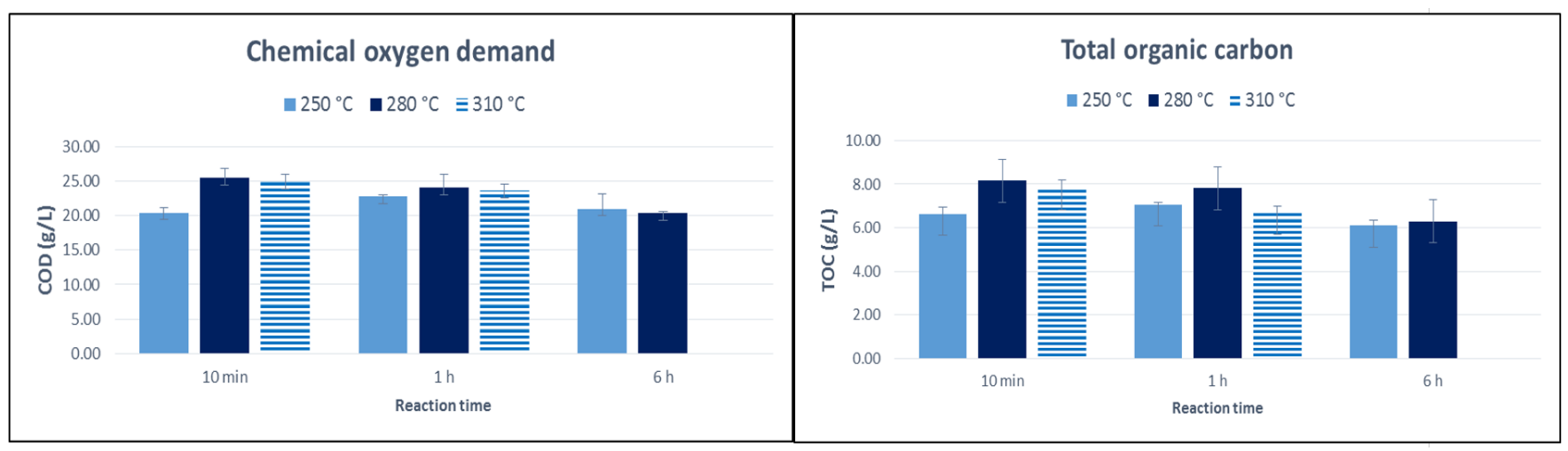

Figure 3. HTC MSW aqueous phase COD and TOC. Error bars represent the standard deviation.

Several organic acids (e.g., lactic and acetic) and sugars were detected in the HTC MSW aqueous phase. The presence of sugars and organic acids are mainly due to the hydrolysis of cellulose and hemicelluloses and their degradation products such as furfural and hydroxymethylfurfural (HMF) [7,9]. HTC aqueous phase is a very complex mixture consisting of many different compounds as reported in literature [7]. The analysis of HTC MSW aqueous phase showed the major organic compounds were acetic acid and lactic acid (Table 1). Major sugars included mannose and xylose. Among other compounds, were trace amounts of formic acid, HMF and furfural. The condition of $280^{\circ} \mathrm{C}$ and $10 \mathrm{~min}$ yielded $13.3 \mathrm{~g} / \mathrm{L}$ of lactic acid which has potential for recovery. The $\mathrm{pH}$ for all aqueous phase samples ranged from 3-4 due to the presence of organic acids. A similar study reported only qualitative data for compounds present the in HTC MSW aqueous phase including acetic acid that was quantified in this study [2]. In this same study, phenols were also identified, and are commonly reported as a hinderances to anaerobic biodegradability.

Table 1. Major compounds in HTC MSW aqueous phase.

\begin{tabular}{cccccc}
\hline T $\left({ }^{\circ} \mathbf{C}\right)$ & Time & $\begin{array}{c}\text { Acetic Acid } \\
(\mathbf{g} / \mathbf{L})\end{array}$ & $\begin{array}{c}\text { Lactic Acid } \\
(\mathrm{g} / \mathrm{L})\end{array}$ & $\begin{array}{c}\text { Mannose } \\
(\mathbf{g} / \mathrm{L})\end{array}$ & $\begin{array}{c}\text { Xylose } \\
(\mathbf{g} / \mathrm{L})\end{array}$ \\
\hline 250 & $10 \mathrm{~min}$ & 0.3 & 8.7 & 2.0 & 0.9 \\
250 & $1 \mathrm{~h}$ & 0.5 & 10.4 & 2.0 & 2.0 \\
250 & $6 \mathrm{~h}$ & 0.5 & 10.1 & 1.9 & 1.6 \\
280 & $10 \mathrm{~min}$ & 0.5 & 13.3 & 1.6 & 2.2 \\
280 & $1 \mathrm{~h}$ & 0.6 & 13.1 & 1.8 & 2.6 \\
280 & $6 \mathrm{~h}$ & 0.7 & 10.4 & 1.2 & 3.1 \\
310 & $10 \mathrm{~min}$ & 0.6 & 13.7 & 2.1 & 3.4 \\
310 & $1 \mathrm{~h}$ & 0.7 & 11.2 & 1.9 & 3.5 \\
\hline
\end{tabular}


The main TOC contributions for the HTC MSW aqueous phase are attributed to the carbonization of the organic components in the feedstock such as paper, food, and plastic. Shredded office paper contributes $45 \%$, almost half of the total HTC feedstock weight, and moreover, is the main material (paper) discarded in landfills. A study conducting HTC on waste paper and recycling of the subsequent process water with process conditions of $200{ }^{\circ} \mathrm{C}$ for $16 \mathrm{~h}$ reported aqueous phase TOC and COD as $9.15 \mathrm{~g} / \mathrm{L}$ and $24.8 \mathrm{~g} / \mathrm{L}$, respectively [18]. The results in this experiment at $280{ }^{\circ} \mathrm{C}$ for $10 \mathrm{~min}$ aqueous phase TOC and COD is $8.16 \mathrm{~g} / \mathrm{L}$ and $25.48 \mathrm{~g} / \mathrm{L}$, respectively (Figure 3). They also identified lactic acid as the most abundant identified organic acid, which is also the case for this experimental data for the HTC MSW experiments. Although reaction conditions vary between the studies, these similarities could provide insight on the influence of paper on HTC aqueous phase composition.

\subsection{Anaerobic Digestion of HTC MSW Aqueous Phase}

The aqueous phases recovered from five HTC conditions were tested to investigate its biodegradability using the AD process. Table 2 shows total biogas production and $\mathrm{mL}$ of biogas produced per gram of TOC and COD. Biogas production ranged from $48-327 \mathrm{~mL}$ biogas/g TOC.

Table 2. Biogas production of HTC MSW aqueous phase and comparisons from literature.

\begin{tabular}{|c|c|c|c|c|c|}
\hline HTC MSW Aqueous Phase & $\mathrm{T}\left({ }^{\circ} \mathrm{C}\right)$ & $\mathbf{t}$ & mL biogas/g COD & mL biogas/g TOC & $\begin{array}{l}\text { Carbon Nitrogen } \\
\text { Ratio (C/N) }\end{array}$ \\
\hline \multirow{5}{*}{ Comparisons from literature } & 250 & $10 \mathrm{~min}$ & 109.4 & 327.4 & 40 \\
\hline & 250 & $1 \mathrm{~h}$ & 15.0 & 48.0 & 61 \\
\hline & 280 & $10 \mathrm{~min}$ & 70.0 & 222.0 & 63 \\
\hline & 280 & $1 \mathrm{~h}$ & 35.5 & 103.3 & 68 \\
\hline & 310 & $1 \mathrm{~h}$ & 24.0 & 84.9 & 57 \\
\hline Corn silage HTC aqueous phase [4] & 220 & $6 \mathrm{~h}$ & & $600 \mathrm{~mL} \mathrm{CH}_{4} / \mathrm{g}$ TOC & 23 \\
\hline Orange pomace HTC aqueous phase [9] & 260 & $2 \mathrm{~h}$ & 295.6 & & - \\
\hline Sewage sludge HTC aqueous phase [17] & 200 & $6 \mathrm{~h}$ & $180 \mathrm{~mL} \mathrm{CH}_{4} / \mathrm{g} \mathrm{COD}$ & & - \\
\hline Food waste HTC aqueous phase [13] & 260 & $4 \mathrm{~h}$ & $58 \mathrm{~mL} \mathrm{CH}_{4} / \mathrm{g} \mathrm{COD}$ & & - \\
\hline Organic fraction MSW HTC aqueous phase [6] & 180 & $1 \mathrm{~h}$ & $205 \mathrm{~mL} \mathrm{CH}_{4} / \mathrm{g} \mathrm{COD}$ & & \\
\hline
\end{tabular}

For these $\mathrm{AD}$ batch test, biogas was quantified as the combination of $\mathrm{CH}_{4}$ and $\mathrm{CO}_{2}$. A retention time of 15 days was used because the aqueous phase requires less time to degrade compared to conventional solid substrates with weeks to months of residence time.

The condition of $280^{\circ} \mathrm{C}$ and 10 min was highlighted to be the most ideal condition in these set of experiments due to its highest TOC yield in the aqueous phase, midrange temperature and shortest residence time of $10 \mathrm{~min}$. Figure 4 shows two set of experiments varying the amount of TOC used at this condition and cumulative gas production of the two TOC concentrations $(0.1 \mathrm{~g}$ and $0.5 \mathrm{~g})$ at $280{ }^{\circ} \mathrm{C}$ for $10 \mathrm{~min}$. Increasing the amount of TOC showed to increase the biogas yield. Literature reports daily biogas production increasing rapidly in the first 7 days due to readily available organics, which was also observed in this set of experiments [9]. Phenols are well known inhibitory compounds to AD performance. Literature reports that with phenol concentrations less than $500 \mathrm{mg} / \mathrm{L}$, substrates were fermented to methane. Phenol concentrations ranging from 800-1200 mg/L, digestion was neither enhanced nor inhibited, but with phenol concentrations greater than $2000 \mathrm{mg} / \mathrm{L}$, inhibition occurred [19]. To rule out any possible phenol inhibition to AD, total phenolics were tested for the $280^{\circ} \mathrm{C}$ for $10 \mathrm{~min}$ condition which resulted in $16.1 \mathrm{mg} / \mathrm{L}$ which is well below reported values of phenol inhibition to AD. 


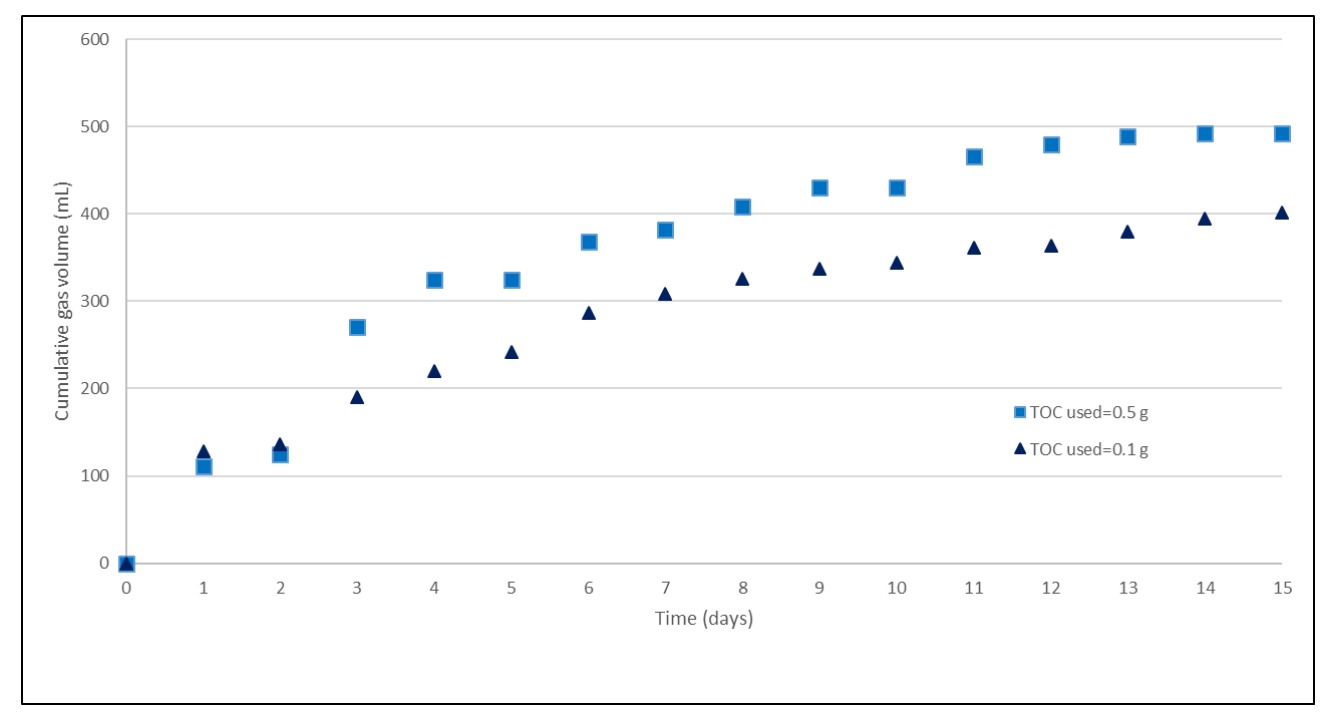

Figure 4. Cumulative biogas production for $280^{\circ} \mathrm{C}$ and $10 \mathrm{~min}(0.1 \mathrm{~g}$ and $0.5 \mathrm{~g}$ TOC).

On average $1 \mathrm{~g}$ COD was used for AD testing. Biochemical methane potential (BMP) is a procedure to determine methane production of an organic substrate during anaerobic biodegradability. $\mathrm{BMP}_{\mathrm{COD}}$ theoretical is calculated based on the conversion of $1 \mathrm{~g} \mathrm{COD}$ producing $0.35 \mathrm{~L} \mathrm{CH}_{4}$ at normal temperature and pressure, to get a sense of the biodegradability of the HTC MSW aqueous phase. Theoretically, $1 \mathrm{~g}$ COD could produce $464 \mathrm{~mL}$ biogas assuming $60 \%$ of the biogas mixture is $\mathrm{CH}_{4}$ [20]. Literature reports biogas yields of $1.9-22.8 \mathrm{~mL} / \mathrm{mL}$ of HTC wastewater used with batch experiments [5]. Other studies have shown biogas yields for sewage sludge process water of $500 \mathrm{~mL}$ biogas/g TOC, and $600 \mathrm{~mL} \mathrm{CH}_{4} / \mathrm{g}$ TOC using corn silage HTC wastewater [21].

It is well known that $\mathrm{AD}$ involves the complex processes of hydrolysis, acidogenesis, acetogenesis, and methanogenesis. Methanogenesis is the energy yielding phase, or the phase which energy yielding products $\left(\mathrm{CH}_{4}\right.$ and $\left.\mathrm{CO}_{2}\right)$ are produced. A major organic component of the HTC MSW aqueous phase was lactic acid ranging from 8.7-13.7 g/L. A study was done that investigated the influence of lactic acid on AD of kitchen waste, as lactic acid is the main fermentation product of kitchen waste during AD. Their study concluded that lactic acid had a negative influence on the performance of methanogenesis as a lower biogas productivity rate was seen during $\mathrm{AD}$ [22]. The condition of $280^{\circ} \mathrm{C}$ and 10 min was the focus of these experiments mainly because of the highest TOC yield in the shortest residence time. Although this condition produced the highest TOC, the condition of $250{ }^{\circ} \mathrm{C}$ produced the highest biogas yield per gram of TOC ( $327.4 \mathrm{~mL}$ biogas/g TOC). Based on the previously mentioned study, lactic acid could affect the production of biogas in the energy producing step methanogenesis. The effects of lactic acid could be monitored for the potential of recovery and/or to improve biogas yields. Paper accounted for almost half the weight percent in the original mixed MSW feedstock. A study on HTC of waste paper performed BMP on the aqueous phase and biogas yields were $730 \mathrm{~mL}$ biogas/g of organic dry matter (ODM); they also noted a trend of faster biodegradability over the first several days due to readily available organic acids [18]. Along with $\mathrm{pH}$, temperature, and concentration, the carbon to nitrogen $(\mathrm{C} / \mathrm{N})$ ratio is an important parameter in overall $\mathrm{AD}$ functionality and biogas production. Literature reports ammonia concentrations below $200 \mathrm{mg} / \mathrm{L}$ are beneficial to the AD process as nitrogen is essential to anaerobic microorganisms [23]. Biogas yields are highly dependent on the $\mathrm{C} / \mathrm{N}$ ratio and optimal ranges are reported as 20-30 [24]. Table 2 also reports the $\mathrm{C} / \mathrm{N}$ ratio of the HTC MSW aqueous phases used for this set of experiments. The condition of $250{ }^{\circ} \mathrm{C}$ and $10 \mathrm{~min}$ yielded the highest $\mathrm{mL}$ biogas/g TOC and subsequently had the lowest $\mathrm{C} / \mathrm{N}$ ratio of 40 - the lowest $\mathrm{C} / \mathrm{N}$ ratio of all other conditions tested. All other $\mathrm{C} / \mathrm{N}$ ratios were in the lower sixties which could explain the lower biodegradability. 
To date and to the best of knowledge, there have been no other studies to test HTC aqueous phase of a mixed MSW feedstock which is the importance of these batch test, to show that it is feasible and can be done. These experiments are a proof of concept that the readily available TOC in the HTC MSW aqueous phase can be a feasible substrate for biogas production. Further studies should investigate using higher TOC concentrations, lactic acid recovery, and potential addition of a co-substrate to increase and maximize biogas production. Nitrogen addition and improving $\mathrm{C} / \mathrm{N}$ ratio is essential in increasing the overall biogas yields and improving the AD system.

\subsection{Solid Phase Composition}

Hydrochar yields ranged from $35-56 \%$ (Table 3 ). The study using a similar feedstock has yields ranging from 29-63\% [2]. The larger yields are due to the unmodified compounds such as the glass and metal. The char type material resulted mainly from the carbonization of the paper, food, and plastic. The lowest hydrochar yield came from the condition of $280^{\circ} \mathrm{C}$ for $6 \mathrm{~h}$ and the highest at $250^{\circ} \mathrm{C}$ for $10 \mathrm{~min}$. At the lower temperature $250^{\circ} \mathrm{C}$ for $10 \mathrm{~min}$, the paper was still in the form of the original feedstock of shredded paper, showing that for this temperature, $10 \mathrm{~min}$ was not enough time to fully carbonize the feedstock to hydrochar.

Table 3. Characteristics of initial feedstock and produced HTC MSW hydrochar.

\begin{tabular}{|c|c|c|c|c|c|c|c|c|c|c|}
\hline & & $\begin{array}{c}\text { TS } \\
(\% \mathrm{DW})\end{array}$ & $\begin{array}{c}\text { VS } \\
(\% \mathrm{DW})\end{array}$ & $\begin{array}{c}\text { Ash } \\
(\% \mathrm{DW})\end{array}$ & $\underset{\text { (wt.\%) }}{\mathrm{C}}$ & $\begin{array}{c}\mathrm{N} \\
\text { (wt.\%) }\end{array}$ & $\begin{array}{c}\mathrm{H} \\
\text { (wt.\%) }\end{array}$ & $\begin{array}{c}\text { O } \\
\text { (wt.\%) }\end{array}$ & $\begin{array}{c}\text { HHV } \\
\text { (MJ/Kg) }\end{array}$ & $\begin{array}{l}\text { Solids Yield } \\
\text { (wt.\%) }\end{array}$ \\
\hline \multicolumn{11}{|c|}{ initial feedstock } \\
\hline \multicolumn{2}{|c|}{ paper } & 93.4 & 92.0 & 7.5 & 37.2 & 0.0 & 5.5 & 49.8 & 14.2 & - \\
\hline \multicolumn{2}{|c|}{ food } & 90.5 & 93.3 & 6.1 & 42.7 & 6.5 & 4.0 & 40.7 & 15.2 & - \\
\hline \multirow{2}{*}{\multicolumn{2}{|c|}{$\begin{array}{l}\text { plastic } \\
\text { hydrochar }\end{array}$}} & 98.1 & 0.0 & 0.0 & 64.0 & 0.0 & 4.3 & 31.7 & 24.1 & - \\
\hline & & & & & & & & & & \\
\hline \multicolumn{2}{|l|}{$\mathrm{T}\left({ }^{\circ} \mathrm{C}\right)$} & & & & & & & & & \\
\hline 250 & $10 \min$ & 93.5 & 94.4 & 4.8 & 47.7 & 0.5 & 5.7 & 41.4 & 19.0 & 56 \\
\hline 250 & $1 \mathrm{~h}$ & 98.6 & 95.0 & 4.8 & 55.1 & 0.9 & 4.9 & 34.3 & 21.3 & 43 \\
\hline 250 & $6 \mathrm{~h}$ & 98.7 & 91.7 & 8.2 & 62.4 & 1.3 & 4.6 & 23.6 & 24.6 & 41 \\
\hline 280 & $10 \mathrm{~min}$ & 99.8 & 93.5 & 6.4 & 60.1 & 1.1 & 4.6 & 27.7 & 23.4 & 39 \\
\hline 280 & $1 \mathrm{~h}$ & 97.4 & 92.5 & 10.5 & 61.5 & 1.3 & 5.0 & 21.7 & 24.9 & 40 \\
\hline 280 & $6 \mathrm{~h}$ & 96.3 & 91.6 & 16.9 & 52.7 & 0.7 & 4.3 & 25.4 & 20.5 & 35 \\
\hline 310 & $10 \min$ & 97.9 & 91.3 & 16.1 & 54.5 & 1.1 & 4.6 & 23.8 & 21.6 & 41 \\
\hline 310 & $1 \mathrm{~h}$ & 91.6 & 84.2 & 21.7 & 58.0 & 1.3 & 5.0 & 13.9 & 24.2 & 41 \\
\hline
\end{tabular}

The elemental composition of hydrochar is presented in Table 3. HTC of the mixed MSW feedstock resulted in HTC MSW hydrochar with higher percentages of carbon with reduced oxygen and ash. From the original feedstock (paper, plastic, food), there was a $40 \%$ increase in the HHV. Ash values ranged from $4.8-21.7 \%$, increasing as residence time and temperature increased. The highest ash value of $21.7 \%$ resulted from the reaction condition of $310{ }^{\circ} \mathrm{C}$ for $1 \mathrm{~h}$. Higher heating values were calculated using a modified Dulong's equation [15] with values ranging from 19-25 (MJ $/ \mathrm{kg}$ ) which compares to the HHV of lower rank coals (e.g., lignite and sub-bituminous).

In other studies, HTC hydrochar trends have shown that as reaction temperature increases, energy content increases and hydrochar yields decrease. Generally, carbon content of hydrochar increases as temperature increases, resulting in an increase of HHV [21]. A trend that was observed for these experiments, is as time increased, HHV increased. Temperature increase causes the decomposition and removal of oxygen rich hemicellulose; therefore, increasing the HHV and fuel value

\section{TGA and BET}

Although the focus of this study was not the hydrochar; thermogravimetric analysis (TGA) and BET surface area analysis were done to investigate potential fuel properties and hydrochar applications based on surface area, respectively. Hydrochar from the conditions 
of $280{ }^{\circ} \mathrm{C}$ and $10 \mathrm{~min}$ were used for these experiments. TGA burning profiles are used to compare the different rankings (i.e., lignite, bituminous etc.) of coal, as each has an idealized burning profile consisting of four elements found within the TGA chromatogram. In classifying coal category, the characterizing point is the "peak temperature (PT)" where weight loss is at the maximum, ranging from below $400{ }^{\circ} \mathrm{C}$ to above $700{ }^{\circ} \mathrm{C}$ [25]. The other components of the burning profile include the ignition temperature (IT), the fixed carbon ignition temperature ( $\mathrm{IT}_{\mathrm{FC}}$ ), and the burnout temperature (BT) [25]. Table 4 compares typical burning parameters of lignite, bituminous and anthracite coals with the HTC MSW hydrochar. The HTC MSW hydrochar temperatures were determined based off the derivative peaks in the TGA chromatogram (Figure 5), which was done in duplicate. Lignite coal's burning profile typically has two peaks which is also seen in the burning profile of the HTC hydrochar signifying some resemblance to lignite grade coals.

Table 4. Comparison of burning parameters of common coal types with experimental HTC MSW hydrochar [25].

\begin{tabular}{cccccc}
\hline & Lignite & Bituminous 1 & Bituminous 2 & Anthracite & \multicolumn{2}{c}{ HTC MSW Hydrochar } \\
\hline IT $\left({ }^{\circ} \mathrm{C}\right)$ & 210 & 350 & 340 & 480 & 270 \\
\hline Main PT $\left({ }^{\circ} \mathrm{C}\right)$ & 500 & 555 & 555 & 665 & 412 \\
\hline BT $\left({ }^{\circ} \mathrm{C}\right)$ & 540 & 665 & 690 & 785 & 660 \\
\hline
\end{tabular}

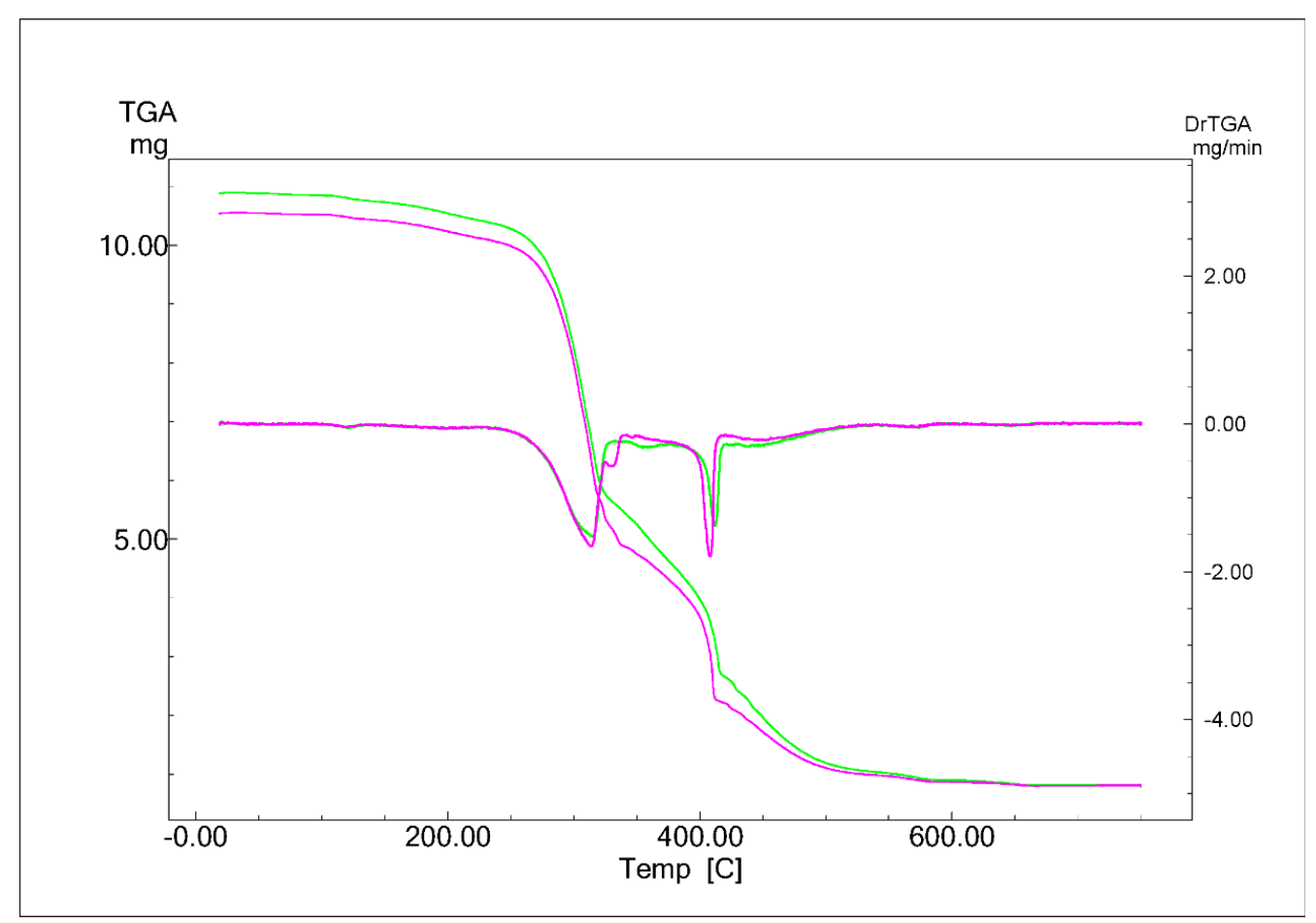

Figure 5. TGA of HTC MSW hydrochar (condition $280^{\circ} \mathrm{C}, 10 \mathrm{~min}$ ) done in duplicate (pink and green lines). Peaks in derivative graph represent the burning profile of the hydrochar.

There is much potential for hydrochar to be used as a soil amendment and even an aid in the AD process due to exposed pores during carbonization. The surface area of this hydrochar was on average $1.2 \mathrm{~m}^{2} / \mathrm{g}$. There is a large range of hydrochar surface areas; however, literature reports that an increase in residence time does allow for modification of cellulose and hemicellulose which can positively affect surface area; 10 min was not enough time to effectively increase pore size and surface area [14]. The hydrochar that was tested had a HTC residence time of $10 \mathrm{~min}$ at $280^{\circ} \mathrm{C}$, which could be a reason for such a small average surface area. Paper, food, and plastic made up the components of the HTC MSW hydrochar. The BET analysis conditions of $95^{\circ} \mathrm{C}$ were chosen because using higher 
temperatures expelled an oily substance from the hydrochar during the analysis. A reason for this is that the boiling point for plastic is around $105^{\circ} \mathrm{C}$, and during the BET analysis any plastic (biocrude) material within the hydrochar could have been modified.

\subsection{Discussion}

\section{Material Balance}

Figure 6 outlines the overall material balance of the two processes that were carried out to better understand the scope of the integrated HTC + AD process. Mass balances were calculated based on how much carbon entered the system and exited the system in the forms of solid, aqueous and gas phases. This figure simulates what would happen if $100 \mathrm{Kg} \mathrm{C}(230 \mathrm{Kg}$ of the mixed MSW) was carbonized and the resulting aqueous phase used for $\mathrm{AD}$, based on the experimental mass balance data for $280^{\circ} \mathrm{C}$ and $10 \mathrm{~min}$ (Figure 2). The liters of biogas are calculated by using the highest experimental biogas yields of $222 \mathrm{~mL}$ biogas/g TOC. Biogas or the combination of $\mathrm{CH}_{4}$ and $\mathrm{CO}_{2}$ were quantified together for these batch $\mathrm{AD}$ experiments; therefore, for this simulation it was assumed that $\mathrm{CH}_{4}$ accounted for $60 \%$ and $\mathrm{CO}_{2}$ accounted for $40 \%$ of the biogas mixture in the calculation of $\mathrm{Kg}$ of $\mathrm{C}$ for biogas. Biogas composition depends on the substrate used but is reported to range from $50-70 \% \mathrm{CH}_{4}$ and $30-40 \% \mathrm{CO}_{2}$ [20].

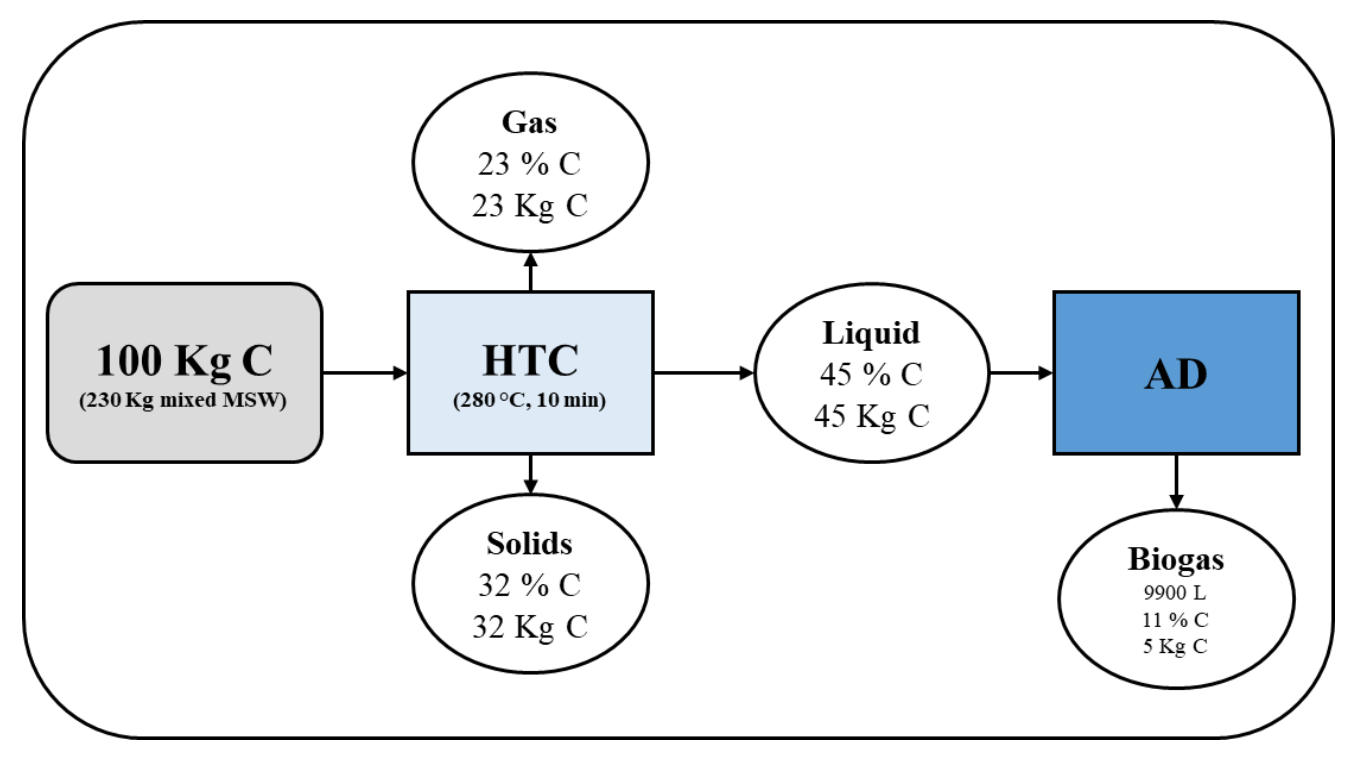

Figure 6. Overall material balance of HTC + AD combined process.

Biogas typically has a thermal value of $22 \mathrm{MJ} / \mathrm{m}^{3}$ and methane with a thermal value of $36 \mathrm{MJ} / \mathrm{m}^{3}$. This process of using $100 \mathrm{Kg} \mathrm{C}$ could result in $218 \mathrm{MJ}$ of energy production based of liters of biogas produced. When evaluating the mass balance, $5 \mathrm{Kg} C$ exits the system as biogas. This now brings into question how to utilize the remaining $40 \mathrm{Kg}(89 \%)$ of carbon, and why it was not digested.

Regarding HTC, there are limited studies investigating the aqueous phase; moreover, the aqueous phase of a mixed feedstock such as the model mixed MSW stream typically headed for the landfill. The closet study to work done in this paper investigates HTC of the organic fraction of MSW (OFMSW) coupled with AD $[6,26]$. The work done by Lucian et al. are great studies specifically for the organic fraction of municipal solid waste; however, this does not consider the fractions that still end up in the landfill (if not separated into organic fractions) and their fate. We have demonstrated that AD is feasible; however, improving digestion is critical in supporting the integrated HTC + AD process for treating MSW. Future testing should evaluate what routes would improve digestion including investigations on improving $\mathrm{AD}$ system conditions by lowering $\mathrm{C} / \mathrm{N}$ ratios with nitrogen addition, aqueous phase pre-treatments, or co-digestion. 


\section{Conclusions}

To date there have been a limited number of studies on HTC of mixed waste materials. The integrated approach (HTC and AD) showed organic carbon recovery of $58 \%$ in the form of hydrochar and biogas. On the commercial scale, HTC plants are considered biorefineries in which the hydrochar has been explored in more detail; however, taking full advantage of all exiting streams such as the HTC aqueous phase will maximize the use of these systems, and make the overall process more environmentally sustainable. To the best of our knowledge, there have been no other reports of investigating and understanding the biodegradability of a mixed MSW stream by varying residence time and temperature. This study is a proof of concept that AD of the HTC MSW aqueous phase is feasible and has potential to be improved upon. Future testing will focus on enhancing biogas yields from aqueous phase, and specific biogas composition. In order to recover, utilize, and maximize aqueous phase carbon, mass balance shows HTC MSW aqueous phase enhancement (e.g., pre-treatment, co-digestion) would be necessary for the integrated system.

Author Contributions: Conceptualization, K.J.A. and S.K.; Data curation, K.J.A.; Formal analysis, K.J.A.; Funding acquisition, B.S. and S.K.; Investigation, K.J.A.; Methodology, K.J.A. and B.S.; Resources, B.S. and S.K.; Supervision, B.S. and S.K.; Writing-original draft, K.J.A.; Writing—review \& editing, K.J.A. All authors have read and agreed to the published version of the manuscript.

Funding: This research was funded by Fiberight, LLC. award number 500298-010.

Acknowledgments: The authors would like to acknowledge the ODU Biomass Research Laboratory (BRL), ODU Department of Civil and Environmental Engineering through which this project has been supported. The authors would also like to thank the ODU Chemistry Department; Oumar Sacko, and the Virginia Atlantic HRSD wastewater treatment plant (David Ewing) for their support in this project.

Conflicts of Interest: The authors declare no conflict of interest.

\section{References}

1. U.S. Environmental Protection Agency (EPA). Advancing Sustainable Materials Management: 2017 Fact Sheet Assessing Trends in Material Generation, Recycling, Composting, Combustion with Energy Recovery and Landfilling in the United States; EPA: Washington, DC, USA, 2019.

2. Berge, N.D.; Ro, K.; Mao, J.; Flora, J.R.V.; Chappell, M.A.; Bae, S. Hydrothermal Carbonization of Municipal Waste Streams. Environ. Sci. Technol. 2011, 45, 5696-5703. [CrossRef] [PubMed]

3. Oliveira, I.; Blöhse, D.; Ramke, H.-G. Hydrothermal carbonization of agricultural residues. Bioresour. Technol. 2013, 142, 138-146. [CrossRef]

4. Wirth, B.; Mumme, J. Anaerobic digestion of waste water from hydrothermal carbonization of corn silage. Appl. Bioenergy 2013, 1, 1-10. [CrossRef]

5. Wirth, B.; Mumme, J.; Erlach, B. Anaerobic treatment of waste water derived from hydrothermal carbonization. In Proceedings of the 20th European Biomass Conference and Exhibition, Milan, Italy, 18-22 June 2012.

6. Lucian, M.; Volpe, M.; Merzari, F.; Wüst, D.; Kruse, A.; Andreottola, G.; Fiori, L. Hydrothermal carbonization coupled with anaerobic digestion for the valorization of the organic fraction of municipal solid waste. Bioresour. Technol. 2020, $314,123734$. [CrossRef] [PubMed]

7. Becker, R.; Dorgerloh, U.; Paulke, E.; Mumme, J.; Nehls, I. Hydrothermal carbonization of biomass: Major organic components of the aqueous phase. Chem. Eng. Technol. 2014, 37, 511-518. [CrossRef]

8. DiStefano, T.D.; Belenky, L.G. Life-cycle analysis of energy and greenhouse gas emissions from anaerobic biodegradation of municipal solid waste. J. Environ. Eng. 2009, 135, 1097-1105. [CrossRef]

9. Erdogan, E.; Atila, B.; Mumme, J.; Reza, M.T.; Toptas, A.; Elibol, M.; Yanik, J. Characterization of products from hydrothermal carbonization of orange pomace including anaerobic digestibility of process liquor. Bioresour. Technol. 2015, 196, 35-42. [CrossRef]

10. Pardo, B.D.M.; Doyle, L.; Renz, M.; Salimbeni, A. Industrial Scale Hydrothermal Carbonization: New Applications for Wet Biomass Waste; ttz Bremerhaven: Bremerhaven, Germany, 2016.

11. Marques, I.P. Anaerobic digestion treatment of olive mill wastewater for effluent re-use in irrigation. Desalination 2001, 137, 233-239. [CrossRef]

12. Posmanik, R.; Labatut, R.A.; Kim, A.H.; Usack, J.G.; Tester, J.W.; Angenent, L. Coupling hydrothermal liquefaction and anaerobic digestion for energy valorization from model biomass feedstocks. Bioresour. Technol. 2017, 233, 134-143. [CrossRef]

13. Zhao, K.; Li, Y.; Zhou, Y.; Guo, W.; Jiang, H.; Xu, Q. Characterization of hydrothermal carbonization products (hydrochars and spent liquor) and their biomethane production performance. Bioresour. Technol. 2018, 267, 9-16. 
14. Kambo, H.; Dutta, A. A comparative review of biochar and hydrochar in terms of production, physico-chemical properties and applications. Renew. Sustain. Energy Rev. 2015, 45, 359-378. [CrossRef]

15. Channiwala, S.; Parikh, P. A unified correlation for estimating HHV of solid, liquid and gaseous fuels. Fuel 2002, 81, 1051-1063. [CrossRef]

16. Funke, A.; Ziegler, F. Hydrothermal carbonization of biomass: A summary and discussion of chemical mechanisms for process engineering. Biofuels Bioprod. Biorefining 2010, 4, 160-177.

17. Hoekman, S.K.; Broch, A.; Robbins, C. Hydrothermal Carbonization (HTC) of Lignocellulosic Biomass. Energy Fuels 2011, 25, 1802-1810. [CrossRef]

18. Weiner, B.; Poerschmann, J.; Wedwitschka, H.; Koehler, R.; Kopinke, F.-D. Influence of process water reuse on the hydrothermal carbonization of paper. ACS Sustain. Chem. Eng. 2014, 2, 2165-2171. [CrossRef]

19. Fedorak, P.M.; Hrudey, S.E. The effects of phenol and some alkyl phenolics on batch anaerobic methanogenesis. Water Res. 1984, 18, 361-367. [CrossRef]

20. Jørgensen, P.J. Biogas-Green Energy; Faculty of Agricultural Sciences, Aarhus University: Aarhus, Denmark, 2009.

21. Reza, M.T.; Andert, J.; Wirth, B.; Busch, D.; Pielert, J.; Lynam, J.G.; Mumme, J. Hydrothermal carbonization of biomass for energy and crop production. Appl. Bioenergy 2014, 1, 11-29. [CrossRef]

22. Zhang, B.; Cai, W.-M.; He, P.-J. Influence of lactic acid on the two-phase anaerobic digestion of kitchen wastes. J. Environ. Sci. 2007, 19, 244-249.

23. Chen, Y.; Cheng, J.J.; Creamer, K.S. Inhibition of anaerobic digestion process: A review. Bioresour. Technol. 2008, 99, 4044-4064. [CrossRef]

24. Dioha, I.; Ikeme, C.H.; Nafi'u, T.; Soba, N.I.; Yusuf, M.B.S. Effect of carbon to nitrogen ratio on biogas production. Int. Res. J. Nat. Sci. 2013, 1, 1-10.

25. Cumming, J.W.; McLaughlin, J. The thermogravimetric behaviour of coal. Thermochim. Acta 1982, 57, 253-272. [CrossRef]

26. Lucian, M.; Volpe, M.; Gao, L.; Piro, G.; Goldfarb, J.L.; Fiori, L. Impact of hydrothermal carbonization conditions on the formation of hydrochars and secondary chars from the organic fraction of municipal solid waste. Fuel 2018, 233, 257-268. [CrossRef] 